\title{
Social technology to prevent intimate partner violence: the VID@ Group in actions with men*
}

\author{
Tecnologia social de prevenção da violência conjugal: \\ o Grupo Vid@em ações com homens \\ Tecnología social de prevención de la violencia conyugal: \\ el Grupo Vid@en acciones con hombres
}

How to cite this article:

Estrela FM, Gomes NP, Pereira A, Paixão GPN, Silva AF, Sousa AR. Social technology to prevent intimate partner violence: the VID@ Group in actions with men. Rev Esc Enferm USP. 2020;54:e03545. DOI: http://dx.doi.org/10.1590/S1980-220X2018040803545

\section{Fernanda Matheus Estrela ${ }^{1}$ \\ Nadirlene Pereira Gomes² \\ Álvaro Pereira ${ }^{2}$ \\ Gilvânia Patrícia do Nascimento} Paixão ${ }^{3}$

Andrey Ferreira da Silva ${ }^{4}$

Anderson Reis de Sousa ${ }^{2}$

* Extracted from the thesis: "Tecnologia Social para homens com vistas a prevenção da violência conjugal”, Programa de

Pós-Graduação em Enfermagem,

Universidade Federal da Bahia, 2018.

${ }^{1}$ Universidade Estadual de Feira de Santana, Departamento de Saúde, Feira de Santana, BA, Brazil.

${ }^{2}$ Universidade Federal da Bahia, Escola de Enfermagem, Salvador, BA, Brazil.

${ }^{3}$ Universidade do Estado da Bahia, Colegiado de Enfermagem, Senhor do Bonfim, BA, Brazil.

${ }^{4}$ Universidade Federal de Alagoas,

Campus Arapiraca, Alagoas, Brazil.

\begin{abstract}
Objective: To disseminate social technology for men aimed at preventing relationship violence developed by the Violence, Health and Quality of Life study group. Method: An experience report about action research aiming at the creation of social technology, based on Paulo Freire's critical-liberating perspective. The target audience consisted of men who had undergone legal proceeding in the Justice Department for Peace in the Home in Salvador (BA). Results: Forty-four (44) men participated in the study. The social technology was organized in eight meetings, the first for presenting the group's proposal and welcoming the participants, the last for evaluative purposes, and the other meetings were thematic with the purpose of encouraging reflection on daily life, aiming at creating and recreating male praxis from the experienced conflicts. Conclusion: Considering the possibility of replication in different scenarios, especially due to the low cost, the use of the technology will enable preventing marital violence resulting from resulting from changing male behavior domestic spaces.
\end{abstract}

\section{DESCRIPTORS}

Violence Against Women; Men; Masculinity; Education; Social Change; Technology. 


\section{INTRODUCTION}

Intimate partner violence represents a complex and large-scale relational phenomenon, mainly due to female mortality rates. This reality requires prevention strategies and coping with the phenomenon, including educational actions with men, as provided for in Law 11.340, better known as the Maria da Penha Law.

Although scientific evidence points to mutual violence between men and women ${ }^{(1)}$, it is the violence instigated by men which mostly affects morbidity and mortality statistics ${ }^{(2)}$. There were 4,645 women murdered in Brazil in 2016 alone. Although these data refer to general homicides, the violence map projects that $47 \%$ of the violence was caused by men with whom the women had an affective relationship ${ }^{(2)}$. However, such damage can be avoided as they are often preceded by initially subtler aggressions, which increase in frequency and intensity over time, often foreshadowing that a fatal outcome is near ${ }^{(2)}$. In understanding that thousands of lives are being taken around the world, intimate partner violence is no longer only treated as a domestic issue, arousing collective and governmental interest $t^{(1)}$.

In this perspective, the state has undertaken the commitment to eradicate violence against women. The year 2006 marked the sanction of the greatest Brazilian advance towards the end of this phenomenon: the creation of the Maria da Penha Law. This instrument to combat violence enabled the prohibition of financial penalties, the arrest of the perpetrator of the aggression in the act, and granting of urgent protective measures ${ }^{(3)}$. Although these measures are intended to make men responsible for their actions, they do not see their attitudes as crime or violence, classifying the Law as unfair and imposing ${ }^{(4)}$.

Such situations have instigated researchers in various parts of the world to develop studies to better understand the phenomenon, as well as unveil strategies for its prevention and coping, as it is well-known that they must permeate gender education of both involved ${ }^{(5,6)}$. This perspective is advocated in the Maria da Penha Law, which shows the need to include the male public in these educational spaces. Article 45 of the aforementioned Law deals with the judge's determination that men attend re-education programs $s^{(4)}$. For such actions to be effective, there is a need to problematize relational issues from the theoretical field of gender, understood as an essential attribute of the person from the social construction. Such a perspective not only encompasses the analytical but also the historical category, pointing out that the differences between men and women must be understood as arising from the social coexistence mediated by culture. In order to understand gender, it is necessary to include the categories race/ethnicity and social class as parameters for the organization of power relations ${ }^{(7)}$.

It is believed that these activities should have a didactic-methodological strategy based on dialogue, problematization and reflection, thus reinforcing the autonomy of the subjects, as proposed by the critical-liberating perspective ${ }^{(8)}$. Such a current involves problematizing issues involving power, domination, oppression, justice, identity, knowledge, culture and liberation. It gives subjects strategies for coping with inequalities, whether economic, social or political in their complexities, such as the phenomenon of violence, through both formal and non-formal education.

The work of reflection groups with transgressive men is inserted in this context. Its importance can be seen from estimates which reveal that men who participated in reflection groups had fewer new episodes of spousal violence (4\%) than those who did not have the same opportunities $(75 \%)^{(6)}$. However, despite their extreme relevance, it is still incipient how these spaces should be conducted ${ }^{(9)}$.

Understanding the magnitude and complexity of conjugal violence, the VID@ Group (founded in 2004, composed mostly of male and female nurses whose perspective is directed towards violence as a health object, as well as with education) has been working since 2011 in producing and enhancing a social technology which can serve as a model for any and all spaces where it can efficiently contribute to male behavioral transformation, as in the sphere of the Family Health Strategy (FHS) of the Ministry of Health, with work targeted at the community. In this sense, this work aims to disseminate social technology for men, developed by the VID@ Group, aimed at preventing intimate partner violence. It is assumed that education represents an effective intervention form in the collective life, thus contributing to building a free and fair society for men and women ${ }^{(8)}$.

\section{METHOD}

\section{Studi DESIGN}

This is an experience report based on the critical-liberating perspective ${ }^{(8)}$. Considering that the terminology social technology has been used to designate reapplicable techniques or methodologies developed in interaction with the community and which represent effective solutions for social transformation, the present study proposes to socialize the methodology of intimate partner violence prevention as emerged through an action and interaction process with men involved in legal proceedings. In order to elaborate a social technology, the VID@ Group developed an action research, a strategy consisting of a study model conceived from an action to solve a collective problem ${ }^{(10)}$.

Thus, action research was conducted from the following phases in seeking to contribute to deconstructing asymmetrical relationships between men and women: diagnosis, action planning, action execution, evaluation and data analy$\mathrm{sis}^{(10)}$. Action research was adopted as a theoretical body and technique for intervention and incorporation specifically on the conduct of actions deemed essential for designing social technology, with the modality of the task-centered operative group being chosen from the perspective of Pichon-Rivière. This group is called the reflection group (RG).

\section{SCENARIO}

The research was conducted in partnership with the $1^{\text {st }}$ and $2^{\text {nd }}$ Justice Courts for Peace in the Home in Salvador, Bahia, Brazil, which opened respectively on November 18, 2008 and March 30, 2015, in the Imbuí and Barris 
neighborhoods. The RGs were scheduled on Thursdays, between $5 \mathrm{pm}$ and $7 \mathrm{pm}$, and were attended in a room of a municipal public school located at the same address as the 1st Justice Court for Peace in the Home.

The study was conducted with 44 men involved in legal proceedings for intimate partner violence in the Justice Courts for Peace in the Home of Salvador.

\section{SELECTION CRITERIA}

The following inclusion criteria were considered: men who had been charged by the Justice Courts due to intimate partner violence, and were considered in good emotional condition. The evaluation of emotional instabilities was performed by the researcher, and in some cases with the support of a psychologist who is part of the Group Vid@.

\section{Data collection}

Data collection was performed between December 2014 and February 2018. Thus, five cycles of RGs were developed, which included the action and interaction process of the men. The first group was held at the end of 2014, setting itself as the pilot, in which attention was paid to surveying the issues which needed adjustments, aiming to better structure the proposal model to be implemented in the next groups. Four subsequent cycles were developed between 2016 and 2017, each with eight weekly meetings, with the exception of the last one - of an evaluative nature - which took place at least one month apart. The interval for the last meeting (of an evaluative nature) was considered essential for participants to assimilate the experience in the RG and to report on their willingness to change the way they relate to family members, especially women. In this sense, each RG had an average duration of three months, with the next RG starting after an interval of two months, with that time being used to evaluate the social technology and establish adjustments, resulting in the presented proposal.

\section{DATA ANALYSIS AND PROCESSING}

The results were based on the reflection on daily life, aiming at creating and recreating male praxis from the experienced conflicts, as proposed by Paulo Freire ${ }^{(8)}$.

\section{ETHICAL ASPECTS}

With regard to obtaining data for research purposes, the study was linked to the doctoral dissertation in Nursing and Health of the School of Nursing of Universidade Federal da Bahia, approved by the Research Ethics Committee of that institution under the opinion 877.905/2014, and complies with the ethical and legal provisions contained in Resolution No. 466/12 of the National Health Council. Data collection was initiated only after men signed the Informed Consent Form (ICF). RGs occurred in a space which ensured privacy during data collection.

\section{RESULTS}

The RG had its operationalization organized into eight meetings, with the first intended to welcome the participants and present the RG proposal, the next six with thematic strand in order to provoke reflections about male perceptions and conduct, as well as their influence on family and partner relations, and the last being of an evaluative character. The methodological presentation of each meeting is described below.

\section{1st Meeting - Presenting the RG}

Objective: To present the didactic-methodological proposal and the purpose of the RG.

Through the dynamic 'Who am I?', all members were introduced: participating men and the work team. It is followed by the presentation of the RG proposal, in which the experiences of previous groups are shared and a schedule of group and dispersed activities is handed out in booklet form. Considering that the executing team is linked to the University and is therefore interested in producing scientific evidence from the developed experiences, it is essential to clarify the intention of using the data for research purposes right from the first moment. However, the use of speech is subject to the authorization of participants, who will have their identities preserved. Their participation in the research is free and voluntary, ensuring the principle of autonomy.

After this step, rules in the RG are agreed upon such as: turrning off or keeping mobile phones in silent mode; avoid showing up late; promote harmonious coexistence through respect for opinions, expressions and emotions emanating during the meetings, even when there is ideological disagreement; and ensuring privacy and confidentiality of exposed personal experiences.

A snack is always conducted at the beginning of each meeting as a way to promote socialization among the men, as an opportunity to broaden bonding relationships with the other participants and with the executing team. Financial support is provided for public transport costs in order to enable effective participation and attendance to the RG.

\section{ND MEETING - INFLUENCE OF THE FAMILY ON THE FORMATION OF THE SELF}

Objective: Incite the value of the family institution and warn of its influence on the reproduction of behaviors.

The dynamics 'Ties and Knots: Knowing the Family Structure' is developed in which men fill out their genogram. It is believed that this process will awaken memories of moments with family members, which are encouraged to be shared during the presentation of the family structure guided by a script: childhood, adolescence and adulthood, including their marital relationship and with their children.

An analogy is made between a fruit tree (Figure 1) and the family tree (Figure 2), which is drawn by highlighting its structures (roots, stem, leaves, flowers and fruits, with the latter considered 'who I am') in which it should be explained that: the root is related to nutrient fixation and absorption; the stem is responsible for nutrient support and conduction; leaves are transpiration, gas exchange and photosynthesis; and the fruits represent the development. The choice of family members that represent the parts of the tree was 
requested, except the fruit, which could be the same person in different parts. The importance of the family foundation for forming the individual is discussed, considering the various models of conformation and family ties, including non- biological ones. It also seeks to stimulate reflections on family members who influenced/determined the person the participant became, represented by the fruit, and also the tendency to reproduce the experienced relationships with the other, especially with children. To emphasize transgenerationality, the video 'Children imitate parents' attitudes', produced by Franco Gregori (https://www.youtube.com/ watch?v=6JxvGbIwud4) was shown, which allows greater reflection on the subject.

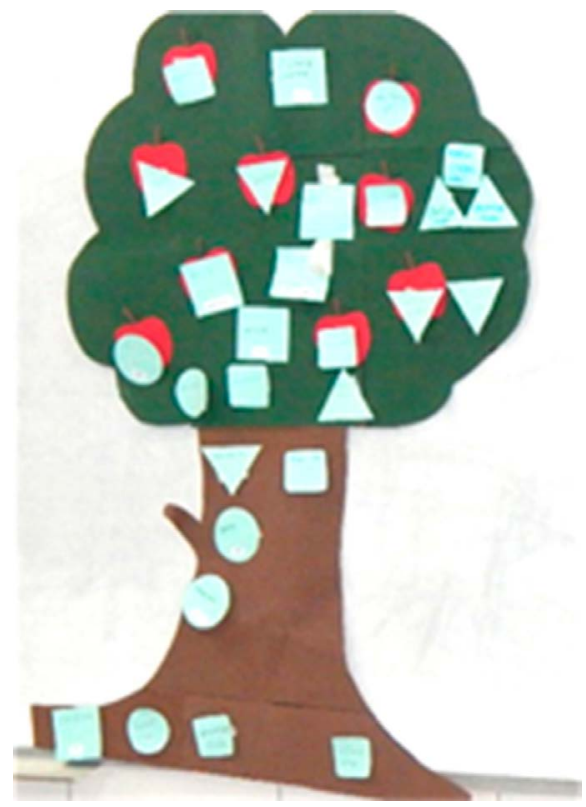

Figure 1 - Fruit tree. Source: Author's archive.

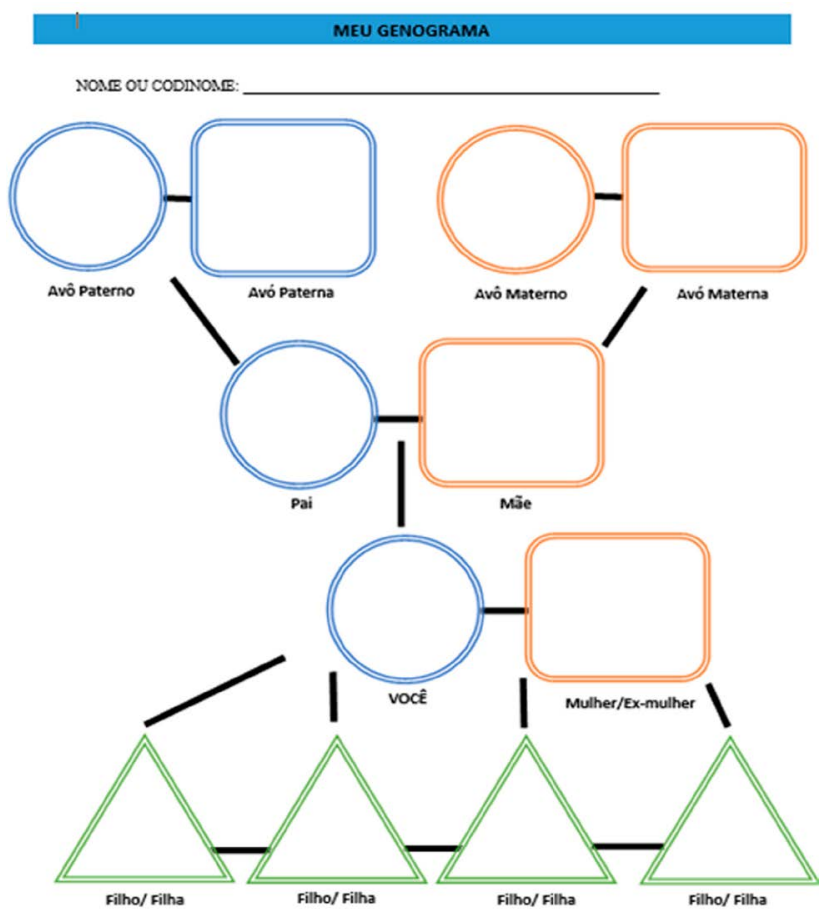

Figure 2 - Family tree. Source: Author's archive.

\section{3rd Meeting - Social construction of Gender} INEQUALITY

Objective: clarify that roles and functions assigned to men and women were historically constructed and reproduced, contributing to the naturalization of male power.

The video 'Gender Equality', produced by the United Nations (United Nations) (https://www.youtube.com/ watch?v=ZCGLC-vziRc) was shown, followed by discussions about gender inequality based on questions: Do you agree with the message brought by the video? What is your opinion about gender equality? Do you believe that inequality can and should be confronted? The objective is to unveil the male perception about "being male" and "being female" and provoke reflections about the social construction of roles/functions considered feminine and masculine, as well as their implications.

The 'Knowing the Reality' dynamic is developed at the end of this stage, displaying true news from newspapers and magazines which address gender inequality, addressing issues such as double shift, differences in management and salary positions, harassment at work, etc. In the discussion, we seek to uncover gender inequality, especially in the public world, which ends up privileging men. The references used to deal with gender issues were structured in the postulates proposed by references in the area ${ }^{(7,11-12)}$.

\section{TH MEETING - MASCULINITIES AND THE FORMATION OF THE "NEW MAN"}

Objective: To warn about the consequences of the hegemonic model of "being a man" for male vulnerability to disease/illness and the need for new models of masculinity anchored in respect and affection.

This meeting is generally only conducted by male members, and begins with the dynamic 'The construction of masculinities', in which one of the participants lies on a metered paper and the others outline the shape of their body with the aid of a marker pen. From the sketch of the exposed drawing, the following questions are made: What is missing in this drawing to constitute a man? How are men taught to behave? What do you have to do to "prove" that you are men? Do you still think that way today? The facilitators note the positions, which serve as a basis for discussion about the elements which build masculinity and their vulnerability to diseases, such as violence.

Finally, the videos 'Old Spice Commercial: The Call of Malvino Salvador' (https://www.youtube.com/ watch?v=bsTGvy5pc04) and 'Sexism also affects the man' (https://www.youtube.com/watch?v=tyty1lfRUoI) are shown, which supports the next discussion: Do you identify with these videos? Is there a relationship between the listed elements and the videos? Is it possible to build a "new man"? The aim is to demystify the hegemonic model of the "macho bread winner" and to raise awareness about the appreciation of attributes based on ethics, respect and affection.

\section{TH MEeTING - Men's HeALTH AND the enCOURAGeMENT OF SELF-CARE}

Objective: To warn about diseases/injuries to which the male population is vulnerable due to the fact of "being a 
man" and to encourage self-care of health, in which healthy marital relationships are inserted.

A human board game is then proposed in order to encourage the practice of self-care focusing on the prevention of both urban and domestic/intimate partner violence (Figure 3), which contains items alluding to the axes advocated by the National Policy for Integral Attention to Men's Health (PNAISH - Politica Nacional de Atenção Integral à Saúde do Homem): Access and welcoming; Sexual and reproductive health; Paternity and care; Chronic diseases and conditions in the male population; Prevention of violence and accidents; Occupational health and mental health. Each thematic category is identified with specific colors and contains a set of questions (for example: Do you practice physical activity? What do you think about condom use? How can we prevent violence in marriage/relationships?), actions (forward and backward) and challenges (For example: making a request for time off to attend a doctor's appointment; putting a condom on plastic penises; changing diapers on dolls). Participants are divided into two groups to start the game and the reps roll the dice to traverse the board, and those who first reach the last house win the game.

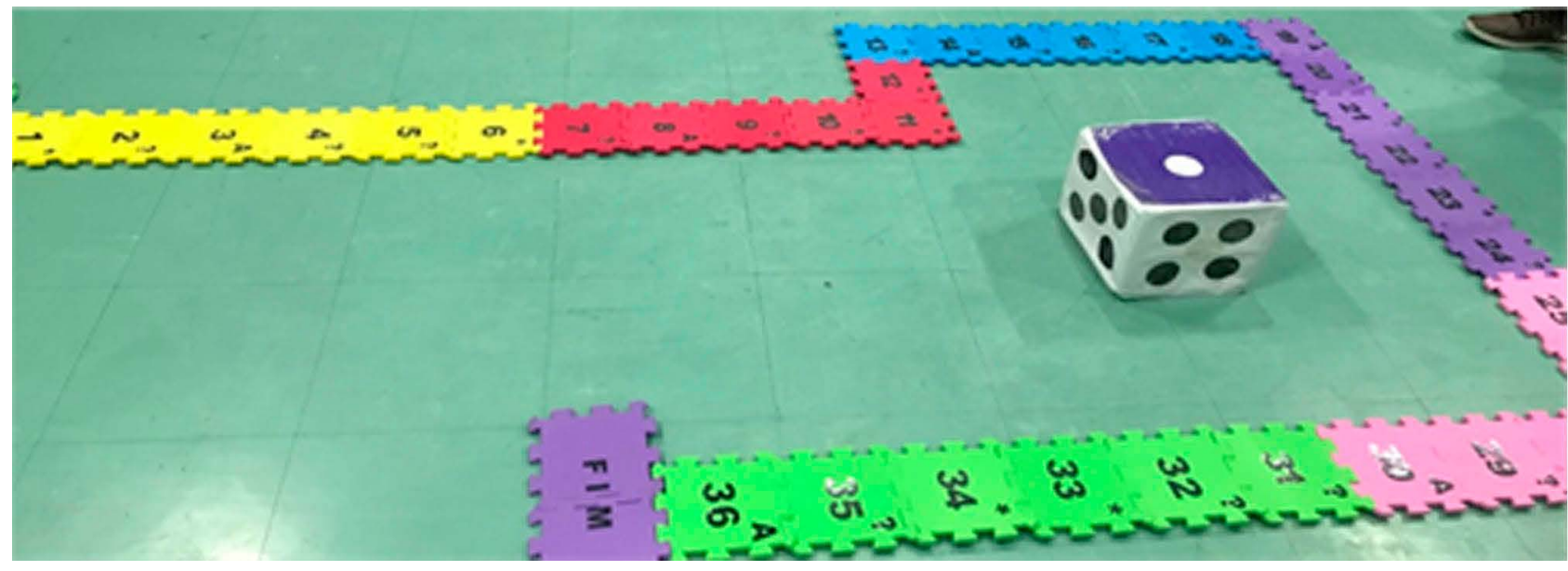

Figure 3 - Human board game. Source: Author's archive

\section{6th MeEting - Perception of VIOlent CONDUCt}

Objective: To encourage male recognition of disrespectful/violent conduct and criminal accountability.

The dynamics 'Clarifying the expressions of violence' is conducted, which aims to give visibility to the various forms of expression of violence, as typified by the Maria da Penha Law. First, five entitled posters are put up on a board, each one representing one of the forms of expression (physical, psychological, moral, sexual and patrimonial). The men are asked to write what comes to their minds when they hear the word violence on pieces of paper, and a piece of paper should be used for each word/phrase, which should then be put up on one of the five posters.

Next, they are encouraged to share why they relate the word/phrase to the form of violence, and to promote a discussion about the veiled character of abuse and the difficulty of men in perceiving their acts as disrespectful/violent and therefore subject to legal penalties, which leads to liability for criminal conduct. Thus, marital conflict is inserted as a problem of public interest, no longer protected by the social belief that "one does not get involved in a fight between husband and wife". To deepen the discussion, but specifically in the field of sexual violence, the video 'Tea and Consent' (https:// www.youtube.com/watch?v=oQbei5JGiT8) is shown, with the purpose of making men reflect on their conduct in marital relations, including marital rape.

\section{7th meeting - Peaceful COnflict Resolution}

Objective: Encourage male perception about precipitating/intensifying elements of intimate partner violence and peaceful conflict resolution strategies.

The dynamic 'Are you stressed? Go fishing!' is developed, in which men catch fish in the simulation of a fishery, with verses containing words which precipitate/intensify intimate partner violence such as jealousy, alcohol and wearing short clothes. After fishing, each participant is asked to verbalize the conflict and mention peaceful settlement strategies. The discussion is broadened for the whole group to list the greatest number of possibilities for conflict resolution other than through violence.

The 'Forgiveness' dynamic is applied in the next step. A large heart-shaped panel is assembled for this in which smaller hearts in different colors containing motivational messages are glued. Each participant chooses a heart and removes it from the panel. Then, each participant is given a printed copy of the story 'The Nails and the Wood', of unknown authorship. After reading the tale, an analogy is made of the marks generated by separating the hearts. The objective is to reflect on the repercussions of their actions for themselves and others. Participants are suggested to exercise forgiveness in daily relationships.

\section{8th meeting - Reflection Group Evaluation}

Objective: To evaluate the impact of the $\mathrm{RG}$ on male transformation, especially regarding family and marital relationships. 
With the objective that the men remember their experiences in the $\mathrm{RG}$, a video is presented containing photos of all the meetings held. Then the dynamics 'So good, Too bad, How about', where pens and three blank posters are given to each participant so that they describe the positive (So Good), negative and/or limitations (Too bad) and suggestions to improve the RG (How about). Such notes should be affixed to the colored posters, respectively represented by the colors green, red and yellow. Then there is space for discussion based on questions such as: Did these meetings provoke reflections about your role as a man, husband, son and father? What has changed in your life from these meetings? This activity makes it possible to evaluate the RG and its contributions to the family and marital relationships of the participants.

Finally, the dynamic 'Mirror reflection' is performed, in which boxes containing a mirror glued to the bottom are provided. All participants are directed to individually observe the contents of the box in a confidential manner and to reflect on the following questions: Who is this person? What has he learned in recent meetings? Has he changed anything in bimself? Participants are encouraged to think about their "I" and the transformations which reverberated from their experiences in the RG.

\section{DISCUSSION}

The choice of the themes worked on, the way they were ordered and the way of conducting the workshop were the result of the researchers' immersion in scientific reading, discussion and practical application, resulting in the social technology disseminated herein. The theme selection was based on the epistemological principle, which values the knowledge brought by the subjects, seeking to overcome limiting situations through dialogue $e^{(8)}$.

Because the family is the essential institution in forming the self and the strongly transgenerational character of violence, this theme is undoubtedly the starting point for reflections on men to begin to emerge, mainly because most of them had never related their childhood experiences to those of adulthood. It was fascinating to hear from the participants themselves during the development of the workshop that they were realizing that they reproduced constructions/behaviors which were learned and/or reproduced from within their own family. During the group mediation process, the work team sought to value the significant experiences brought by the subjects, encouraging them to re-read their own world ${ }^{(8)}$. There was also an interest in promoting understanding about the gender constructions implied in the formation of the subjects, since they present themselves as cultural forms and meanings which give meaning to life, in addition to promoting characteristics considered socially as feminine and masculine ${ }^{(11)}$. In this sense, addressing themes which bring out the social role of the family as a shaper of individual identity is important because it favors reflection and reframing of violent behavior in family and intimate partner relations ${ }^{(5,6)}$.

The main mentioned legacy refers to a division in roles between men and women, strongly rooted in the patriarchal model, socially taught and reproduced in their homes. This perspective is discussed by a gender theorist when they point out that men and women are built by historical, cultural and social constraints, permeated by power relations, making the feminine figure remain in a condition of subordination ${ }^{(11)}$, favoring the practice of violence in marital relations. National research adds that this social construction reinforces the non-recognition of violent situations ${ }^{(1)}$, which are therefore understood as natural. This naturalization of violence can also be understood from the Freirean perspective, which starts from the premise that neutrality would be the most comfortable, if not the most hypocritical, way to hide the option or the fear of accusing injustice. In gender-based reading, the issue of neutrality gains in scope as it is rooted in patriarchy and should therefore be comprehensively analyzed. Some reasons for gender inequalities and consequent female oppression are explained based on this ${ }^{(7)}$.

Thus, in order to overcome reality, understanding and recognizing the phenomenon are fundamental for transforming society ${ }^{(8)}$. In this context, providing reflections on the importance of deconstructing gender inequalities learned in childhood becomes the next theme in the flow of the social technology presented herein.

It must be mentioned that it is these socially established differences which make women and men vulnerable to the experience of violence. In addition to making women vulnerable, power, which is symbolically presented in male domination, imposes the legitimacy of men and sustains gender disparities, which naturalize and mask in relationships, infiltrating into the thinking and world concept ${ }^{(12)}$.

Worldwide studies show the higher morbidity and mortality of women due to the experience of intimate partner violence $^{(1)}$, as well as the high morbidity and mortality of men due to external violence ${ }^{(2)}$, in addition to their illness from domestic violence ${ }^{(4)}$.

Thus, we discuss the various existing masculinities in an attempt to break taboos such as "men do not cry", so that men can assume a position of change about the hegemonic model of masculinity. From a gender perspective, power relations are present in the way of conceiving the masculine and the feminine identities, denouncing existing dichotomies, oppositions and prejudices, and those "invisible concepts" which make up universes of unequal socialization ${ }^{(12)}$. The aim here is to work on appreciating attributes based on respect and male affection. These ideas are also defended in the axiological principle, which argues that education should produce and disseminate positive values which contribute to humanization and solidarity of the subjects ${ }^{(8)}$. In this sense, programs from the perspective of gender and masculinity are necessary to change attitudes and behaviors ${ }^{(5-6)}$ historically and socially structured ${ }^{(7)}$, thus favoring the construction of the new man.

The aforementioned workshop is also of paramount importance, because illness and even suicide statistics among men around the world are high, as they are deprived of the right to share their fears and anxieties. In addition, a Canadian study with men reveals that there is a high rate of male suicides due to the difficulty of talking about their problems and being lonely ${ }^{(13)}$. It is precisely because of such 
realities, as in the case of male suicide statistics, that Freire's thoughts were sought to be put into practice, since Paulo Freire himself defends the constant struggle against any form of oppression, proposing that education be guided by ethics of the development of human life in its various potentialities, promoting dignity and fostering the responsible autonomy of subjects in relation to themselves and the community ${ }^{(8)}$. This hegemonic masculinity model, which characterizes men as strong, courageous and virile, puts men at risk, contributes to violence against women, and demands affective and emotional renunciation such as parenting and expressing feelings ${ }^{(12)}$.

It is also recalled that much of this construction about the strong and virile man causes this group to distance themselves from health services ${ }^{(4)}$. Thus, during the construction of this social technology to prevent intimate partner violence, talking about health and encouraging men to perform self-care unveiled topics of paramount importance. From this perspective, we tried to make life habits become a reflection object by the men, constituting an essential condition for critical understanding of their own practice and consequent change in behavior ${ }^{(8)}$. The gender issues which permeate these constructions are closely articulated with language and discourse, forming a symbolic universe which enables one to socially analyze what is seen in the bodies ${ }^{(11)}$.

This is mainly because this space allows us to go deeper into the issue of violence, since it is based on PNAISH. With many issues discussed and demystified, starting from the sixth meeting, the technology proposes to effectively denaturalize violent conduct. This is because even though there are many forms of expressing intimate partner violence, they are often not understood as such, especially when it comes to the subtler, non-marking forms ${ }^{(4)}$. It is also inferred that there is no way to put an end to something that is not understood. Thus, causing reflections and understanding about all forms of violence based on the Maria da Penha $\mathrm{Law}^{(3)}$ turns out to be the focus of this meeting. In this sense, education is a diffuser and producer of values which govern the lives of subjects, and this should contribute to a freer and fairer society and to overcoming the various forms of exploitation and domination in force ${ }^{(8)}$. Male domination is tenuous in relationships, often invisible, settled in our unconscious, masked in simple ways of organizing thought and language, and thus need to be tensioned ${ }^{(12)}$.

In understanding that their actions were violent, men are urged to create strategies for peaceful conflict resolution. Given that there are many elements which precipitate marital violence ${ }^{(1)}$, nothing works better than the men themselves reflecting on how to solve these problems without the use of force, using the exercise of self-perception as a mobilizing action to create new resolution strategies for the conflicts ${ }^{(5-9)}$.

Finally, in arriving at the evaluation meeting and hearing from men who were once resistant, how important were the spaces created by this tool was rewarding. From the technology aspect which enables men to reflect on their lives, share stories and awaken themselves to new life projects, such experience indicates that this is an effective resource for preventing intimate partner violence. In agreement with the critical-liberating perspective, it is believed that male reflection, action and participation, to the detriment of banking education, constitute an important weapon to prevent and confront this problem.

Although the study has limitations because it does not contemplate all the possibilities of themes to be explored, it is considered that the approached contents have potential for change and may even be replicated in schools, companies and health services, especially in the context of community through the FHS. It is also important to mention that the methodological strategy presented herein can and should be implemented with new groups, including adolescents.

\section{CONCLUSION}

The social technology for men aimed at preventing intimate partner violence developed by the VID@ Group is based on stimulating reflection on male perceptions and behaviors regarding how they relate to women. To do so, discussion spaces are promoted to make men rethink the importance of the family in forming the individual and the impacts of gender inequality on society, demystifying the hegemonic model of the "macho bread winner", as well as to encourage them to practice self-care, know/recognize the various forms of violence expression, and elect peaceful methods of conflict resolution.

It is evident that it was necessary to operationalize the work from intersectoral, interdisciplinary and multiprofessional articulation, institutional consent, bioethics and public funding for access to the involved institutions and to the participating men in order to implement the social technology presented herein. In addition, the theoretical survey, presentation of the didactic-methodological proposal and the meetings were developed through teamwork.

It is believed that multiplying educational spaces may not only favor the denaturalization of abuse against women, but also insert men into confronting this problem, making them transforming agents of collective reality and co-responsible for the construction of a freer, just society which is equal between men and women.

\section{RESUMO}

Objetivo: Divulgar tecnologia social para homens, desenvolvida pelo grupo de estudos Violência, Saúde e Qualidade de Vida, visando à prevenção da violência conjugal. Método: Relato de experiência acerca de uma pesquisa-ação visando à criação de tecnologia social, fundamentada na perspectiva crítico-libertadora de Paulo Freire. O público-alvo foi composto por homens que respondiam a processos nas Varas de Justiça pela Paz em Casa, em Salvador (BA). Resultados: Participaram 44 homens. A tecnologia social foi organizada em oito encontros, sendo o primeiro destinado à apresentação da proposta do grupo e ao acolhimento dos participantes, o último com fins avaliativos, e os demais, de caráter temático, com o objetivo de incitar a reflexão sobre o cotidiano, visando à criação e recriação das práxis masculinas a partir dos conflitos vivenciados. Conclusão: Considerando a possibilidade de replicação em diferentes cenários, sobretudo em decorrência do baixo custo, o uso da tecnologia possibilitará a prevenção da violência conjugal a partir da transformação masculina. 


\section{DESCRITORES}

Violência contra a Mulher; Homens; Masculinidade; Educação; Mudança Social; Tecnologia.

\section{RESUMEN}

Objetivo: Divulgar la tecnología social para hombres, desarrollada por el grupo de estudios Violencia, Salud y Calidad de Vida, con vistas a la prevención de la violencia conyugal. Método: Relato de experiencia acerca de una investigación-acción a fin de crear la tecnología social, fundada en la perspectiva crítica y libertadora de Paulo Freire. El público meta estuvo compuesto de hombres que respondían a demandas en los Juzgados por la Paz en el Hogar, en Salvador (BA). Resultados: Participaron 44 hombres. La tecnología social fue organizada en ocho encuentros, siendo el primero destinado a la presentación de la propuesta del grupo y a la acogida de los participantes, el último con fines de evaluación, y los demás, de carácter temático, con el fin de incitar la reflexión acerca del cotidiano, con vistas a la creación y recreación de praxis masculinas a partir de los conflictos vividos. Conclusión: Considerando la posibilidad de replicación en distintos escenarios, sobre todo como resultado del bajo costo, el empleo de la tecnología posibilitará la prevención de la violencia conyugal a partir de la transformación masculina.

\section{DESCRIPTORES}

Violencia contra la Mujer; Hombres; Masculinidad; Educación; Cambio Social; Tecnología.

\section{REFERENCES}

1. Paixão GPN, Pereira A, Gomes NP, Souza AR, Estrela FM, Silva Filho URP, et al. Naturalization, reciprocity and marks of marital violence: male defendants' perceptions. Rev Bras Enferm [Internet]. 2018;71(1):178-84. DOI: http://dx.doi.org/10.1590/0034-7167-2016-0475

2. Evoy CMC, Hideg G. Global violent deaths 2017. Time to Decide. Switzerland: Small Arms Survey; 2017.

3. Brasil. Lei n. 11.340, de 7 de agosto de 2006. Cria mecanismos para coibir a violência doméstica e familiar contra a mulher, nos termos do $\S 8^{\circ}$ do art. 226 da Constituição Federal, da Convenção sobre a Eliminação de Todas as Formas de Discriminação contra as Mulheres e da Convenção Interamericana para Prevenir, Punir e Erradicar a Violência contra a Mulher; dispõe sobre a criação dos Juizados de Violência Doméstica e Familiar contra a Mulher; altera o Código de Processo Penal, o Código Penal e a Lei de Execução Penal; e dá outras providências [Internet]. Brasília; 2006 [citado 2018 ago. 12]. Disponível em: http://www.planalto.gov.br/ccivil_03/_ato2004-2006/2006/ lei/L11340.htm

4. Sousa AR, Gomes NP, Estrela FM, Paixão GPN, Pereira A, Couto TM. Domestic violence: the discourse of women and men involved in criminal proceedings. Esc Anna Nery [Internet]. 2018 [cited 2018 Aug 30];22(1):e20170108. Available from: http://www.scielo.br/scielo. php?script=sci_arttext\&pid=S141481452018000100204\&lng=en

5. Fleming PJ, Gruskin S, Rojo F, Dworkin SL. Men's violence against women and men are inter-related: recommendations for simultaneous intervention. Soc Sci Med. 2015;146:249-56. DOI: 10.1016/j.socscimed.2015.10.021

6. Paixão GPN, Pereira A, Gomes NP, Campos LM, Cruz MA, Santos PFM. A experiência de prisão preventiva por violência conjugal: o discurso de homens. Texto Contexto Enferm [Internet]. 2018 [citado 2019 abr. 23];27(2):e3820016. Disponível em: http://www.scielo.br/ scielo.php?script=sci_arttext\&pid=S0104-07072018000200327\&lng=pt

7. McCarthy KJ, Mehta R, Haberland NA. Gender, power, and violence: a systematic review of measures and their association with male perpetration of IPV. PLoS One [Internet]. 2018 [cited 2019 Mar 21];13(11):e0207091. Available from: https://www.ncbi.nlm.nih.gov/ pmc/articles/PMC6264844/

8. Garzon AMM, Silva KLD, Marques RC. Liberating critical pedagogy of Paulo Freire in the scientific production of nursing $1990-2017$. Rev Bras Enferm [Internet]. 2018 [cited 2019 Mar 21]; 71; Suppl 4:1751-8. Available from: http://www.scielo.br/scielo.php?script=sci_ arttext\&pid=S0034-71672018001001751\&lng=en\&tlng=en

9. Jewkes R, Flood M, Lang J. From work with men and boys to changes of social norms and reduction of inequities in gender relations: a conceptual shift in prevention of violence against women and girls. Lancet. 2018;385(9977):1580-9.

10. Thiollent M. Fundamentos e desafios da pesquisa-ação: contribuições na produção dos conhecimentos interdisciplinares. In: Toledo RF, Jacobi PR, organizadores. A pesquisa-ação na interface da saúde, educação e ambiente: princípios, desafios e experiências interdisciplinares. São Paulo: Annablume; 2012. p. 19-39.

11. Alves AM. Pensar o gênero: diálogos com o Serviço Social. Serv Soc Soc [Internet]. 2018 [citado 2019 mar. 21];(132):268-86. Disponível em: http://www.scielo.br/scielo.php?script=sci_arttext\&pid=S0101-66282018000200268\&lng=pt\&tlng=pt

12. Assunção MFM. Notas sobre a dominação social em António Gramsci e Pierre Bourdieu. Sociologia [Internet]. 2016 [citado 2019 mar. 21];31:151-71. Disponível em: http://www.scielo.mec.pt/scielo.php?script=sci_arttext\&pid=S0872-34192016000100008\&lng=pt\&tlng=pt

13. Roy P, Tremblay G, Duplessis- Brochu E. Problematizing men's suicide, mental health, and well-being. Crisis. 2018;39(2):137-43. DOI: 10.1027/0227-5910/a000477

\section{Financial support:}

Fundação de Amparo à Pesquisa do Estado da Bahia (FAPESB). Public Security Secretariat, which provided funding for project development. Request number 6897/2013. 